\section{原 著}

\title{
収集データの精度向上を目的としたPET 画質評価実験法の検討
}

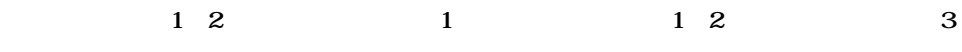 \\ 福士政広 ${ }^{2)} \cdot$ 黑沢秀雄 $^{1)} \cdot$ 田仲 隆 ${ }^{1)}$ \\ 1 )国立がんセンター東病院放射線部 \\ 2 ) 首都大学東京大学院保健科学研究科 \\ 3 ) GE 横河メディカルシステム株式会社画像応用技術センター
}

論文受理

2006 年 8 月29日

Code No. 523

緒 言

positron emission tomography (PET) 装置の性能評価

方法としてNational Electrical Manufacturers A ssocia tion(NEMA NU-22001)1) International Electrotechnical Commission²)から光れ光れ規格が示されている. 国内 では日本画像医療システム工業会からJESRA X-73規 格泉が示されている．一方で, 急速に増加しつつある PET検査施設に対して， ${ }^{18}$ F-FDG-PET検査の技術指針 として本学会からPET画像の標準化ガイドラインに関 する研究班報告 ${ }^{4}$ が示されている. 兴のため, 各施設 においてPET検査の質を担保するためにファントムを 用いた品質保証 (quality assessment)や品質管理(quality control)を行う必要がある.さらに, 臨床における収 集条件や画像処理条件などを決定する場合, 放射能分
布や患者の体格が異なるため厳密な評価は不可能であ るが，兴の収集条件に対する画質の特徵を把握するた めファントムを用いた画質評価を行うことが一般的で ある .ファントムを用いた画質評価は収集条件の一つ の決定因子となることから，关の役割は大きい，PET で得られる画質は，収集カウントの減少に伴い統計ノ イズの影響が大きくなることから , データのバラツキ が大きくなり，得られる実験結果が異なる5). 兴のよ うな状況を再現したファントム実験において得られる データは評価データとして信頼性に欠ける．关のた め, 複数回の実験を行い信頼性を高めることか理想的 である.しかし, 計数率の変化による影響, 核種の減 衰 , ファントム作成の再現性などの問題により非常に 複杂隹なものとなる．また，実験に伴う術者被曝線量の

\section{Examination of PET Image Evaluation Experimentation Method Aiming at Improved A ccuracy of Data A cquisition}

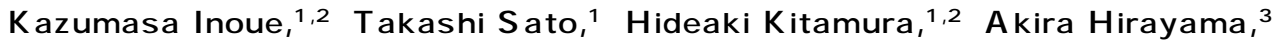
Masahiro Fukushi, ${ }^{2}$ Hideo Kurosawa, ${ }^{1)}$ and Takashi T anaka ${ }^{1}$ )

1 ) Department of Radiology, National Cancer Center Hospital East

2 ) Graduate School of Health Sciences, Tokyo Metropolitan University

3 ) Imaging Application Technology Center, GE Yokogawa Medical Systems, Ltd.

Received June 19, 2006; Revision accepted August 29, 2006; Code No. 523

\section{Summary}

Multiple data evaluation is desirable for data obtained by positron emission tomography (PET), as the data follow the Poisson distribution. Such evaluation, however, tends to be very complicated, since the countrates change with nuclide decay. To solve this problem, we propose a new data scan protocol in this communication. With this method, the true+scatter coincidence counts were computed during the initial oneminute scanning, which was fixed as the standard. A dynamic scan was then performed with the fixed counts from the high count-rate region. Regions with $\pm 2.5 \%$ of the image noise of the standard image was chosen to provide the data for evaluation. These were found to be the regions of $16.5-25.5 \mathrm{kcps}(2 \mathrm{D})$ and $81.1-138.5$ kcps. I mage quality was found to be affected by noise(2D)and random coincidence. U sing this method, multiple data could be obtained by a single experiment, and very reliable image evaluation could be done.

K ey words: image quality, count rate, detectability, image noise, positron emission tomography (PET)

別刷資料請求先：=277-8577 千葉県柏市柏の葉6-5-1

国立がんセンター東病院放射線部 井上一雅 宛 
増加も懸念される. そこで本研究では, 高計数率領域 より真の同時計数と散乱同時計数を一定にしてダイナ ミック収集を行い，偶発同時計数が画質に与える影響 を検討して，これらの問題を解決するための新たなデ 一タ収集方法を検討したので報告する．

\section{1 . 使用機器}

本研究において使用したPET /CT装置はDiscovery ST (GE Healthcare)である . 本装置には長さ54mm , 厚 さ $0.8 \mathrm{~mm}$ のタングステン製の着脱可能なセプタが装備 されており，二次元(2D)収集および三次元(3D) 収集 が可能である . シンチレータは $\mathrm{B}_{4} \mathrm{G}_{3} \mathrm{O}_{12}$ (bismuth germanate)検出器6.3×6.3×30mmであり，6×6 配列の 結晶ブロックで構成されている . 体軸方向の視野は 157mmで , 47スライスを有している . エネルギーウィ ンドウは375〜650keVで, 同時計数タイミングウィン ドウは11.7nsである．断面内分解能(NEMA NU-2 2001 : $\mathrm{R}=1 \mathrm{~cm})$ は5.18mm(2D)，5.97mm(3D)，体軸方 向分解能は6.13mm(2D)，6.11mm(3D)である．感度 (NEMA NU-2 2001 : R=Ocm)は , 1.93cps/kBq(2D ), 9.12cps/kBq(3D) である . 散乱フラクション (scatter fraction : SF )(19.1\% (2D ) , 45.1\% (3D )である6). ークステーションはX eleris(GE Healthcare)を使用し た .また，使用したファントムは，大きさの異なる六 つの球を有するNEMA NU-2 2001 IQファントムと , 長さ70cmの散乱ファントムを用いて実験を行った . 球の内径は光れ光れ10，13，17，22，28，37mmであ る .

\section{2 . 実験方法}

\section{2-1 データ収集方法}

本研究では, 腹部骨盤領域における描出能評価(病 変部脂肪組織)を想定し , バックグラウンド (BG) 領 域: $2 \mathrm{kBq} / \mathrm{mL}$, 球( $\mathrm{HOT}$ )領域 : $8 \mathrm{kBq} / \mathrm{mL}$ の放射能濃 度を基準値とした。しかし，本実験では，計数率の影 響を評価するため，基準値の3 倍量の放射能濃度 (BG：6kBq/mL，HOT：24kBq/mL) )実際に充填した . また，視野外散乱線を考慮した画質評価が一般的であ ることから , 散乱ファントムに100MBq(17kBq/mL) を充填し視野外に設置した．収集方法は，2D収集お よび3D収集とし，HOT領域の中心を体軸方向視野中 心に設置し収集した．初めに1分間収集を行い，得ら れた真の同時計数+散乱同時計数 (Trues+Scatters : $\mathrm{T}+\mathrm{S})$ のカウント $\left(C_{1 \mathrm{~min}}\right.$ : kcounts) を基準として , 各撮 像時間相当のカウント $\left(C_{t}: \mathrm{kcounts}\right)$ を算出し , 続けて 各フレームにおいてT+Sが同一カウントとなるように 収集カウントを制御したダイナミック収集(50frame) を行った . $C_{t}$ の算出方法を式(1)に示す.

$$
C_{t}=\frac{\left(A_{0(B . G .)} / K\right)}{A_{t(\text { B.G. })}} \times C_{1 \min } \times T
$$$$
A_{t(B . G .)}=A_{0(B . G .)} e^{-\lambda t}
$$

$$
\lambda=\frac{0.693}{t_{1 / 2}}
$$

ここで， $A_{\text {O(B.G.) }}$ はB.G.領域の充填放射能(MBq)， $A_{t(B . G .)}$ は 1 分間収集開始時の放射能 $(\mathrm{MBq}), K$ は倍量(本実 験では基準値BG放射能濃度の 3 倍量），Tは収集時間 $(\min ) て ゙ あ る . \lambda$ は壊変定数, $t$ は 1 分間収集開始時 刻， $t_{1 / 2}$ は ${ }^{18} \mathrm{~F}$ 放射性核種の半減期(109.8分)である.式 (1)より得られた $C_{t}$ は, BG領域が $2 \mathrm{kBq} / \mathrm{mL}, \mathrm{HOT}$ 領 域が $8 \mathrm{kBq} / \mathrm{mL}$ のとに $T$ 分間収集したときのT+Sの力 ウントとなる. 本方法は, ${ }^{18} \mathrm{~F}$ 用いた場合を想定し ており，短半減期核種では収集時間内の減衰の影響が 無視できないと考える．

本実験では, 1 分間収集後に式(1)より $T=5$ 分とし て 5 分収集相当のカウント $C_{5 \mathrm{~min}}$ を算出し , 続けて収集 カウント制御によるダイナミック収集 $\left(C_{5 \min } \times 50\right.$ frame $)$ を行った .

\section{2-2 データ処理方法}

2D収集の画像再構成方法は, ordered subsets expectation maximization(OSEM )法7)を用い，3D収集では， Fourier rebinning(FORE)法8)，OSEM法を使用した . OSEM法の再構成条件は当院ルーチン検査て使用して いるsubset : 14(2D) , 16(3D), iteration : 2(2D ), 3 (3D)であり，画像ノイズ，コントラスト分解能など を考慮して決定した条件である。また，FWHM 4.29mmの前処理フィルター(サイノグラム空間におけ る一次元ガウス平滑化処理), FWHM 3.91mmの後処 理フィルター(再構成画像に対する二次元ガウス平滑 化処理)を用いた．吸収補正方法はCTによるMAC法 とし, 散乱同時計数補正は, de-convolution法(2D $)^{9)}$, model-based technique法 $(3 D)^{10)}$ を用いた . 偶発同時計 数補正は遅延同時計数回路を用いたreal time subtraction法(2D，3D ) 11)を使用した．また，不感時間補正， 減衰補正(収集開始時刻に起算し補正)を行った。

\section{2-3 データ解析方法}

同一条件下で収集した計数率の異なるデータ間にお いて , 体軸方向1/4点から体軸中心に3スライスにわた り, BG領域に18cmфのROIを各スライスに設置し, 式 (4)により変動係数(coefficient of variation : $C O V$ )を得 た.さらに, 式(5)より実際に収集時間が5分(BG放射 能濃度 $=2 \mathrm{kBq} / \mathrm{mL})$ となったフレームのCOVを基準 $\left(C O V_{r e f}\right)$ として $\triangle C O V$ 算出した . 


$$
\begin{aligned}
& \operatorname{COV}(\%)=\frac{\text { S.D. }}{\text { Average }} \times 100 \ldots \ldots . . . \\
& \Delta \operatorname{COV}(\%)=\frac{C O V-C O V_{\text {ref }}}{C O V_{\text {ref }}} \times 100
\end{aligned}
$$

ここで，S.D.は標準偏差，AveragelはROI設置領域内の ピクセル值の平均值である. 本研究では $\triangle C O V$ が基準 值から $\pm 2.5 \%$ 範囲を評価対象データとした .また， 評価対象とする計数率領域を決定する際に，データの バラツキを考慮して近似直線を用いた．次に，式(6) により部分容積効果の影響の少ない37mm 域およびBG領域にROIを設置しlesion/background(L/ B)比を算出した .

$$
\text { lesion / background }=\frac{H O T-S U V_{\text {mean }}}{B . G .-S U V_{\text {mean }}}
$$

ここで, HOT-SUV $V_{\text {mean }}$ は, HOT領域の平均SUV 值 (ROI：37mm $\phi), B . G .-S U V_{\text {mean }}$, HOT領域近傍のBG 領域の平均SUV 值(ROI：50mm $\phi)$ である .

\section{3. 結 果}

\section{3-1 収集カウントの変化}

式(1)より， $C_{1 \mathrm{~min}}$ はそれ炎れ3209kcounts(2D )， 16835kcounts(3D)であり，C $C_{5 \mathrm{~min}}$ はとれ光れ6406kcounts (2D ) , 33486kcounts(3D )であつた . Fig. 1 , 2に2Dお よび3D収集におけるBG 領域の放射能濃度 (BGA ctivity) (対する全同時計数(Prompt)，T+S, 偶発同 時計数の変動および $C_{5 \min }$ を得るために必要とした収集 時間を示す. 光の結果, カウント制御により収集を行 つたためT+Sの収集カウントが一定となり，偶発同時 計数か時間経過に伴い減少傾向にあった．また，実際 の収集時間が 5 分となったとき,BG-Activityは設定 值の $2 \mathrm{kBq} / \mathrm{mL}$ であつた . 本実験における合計収集時 間は，6 時間45分(2D)，7 時間45分(3D)であった .

\section{3-2 計数率の変化}

Fig. 3 ，4にBG-A ctivityに対する2Dおよび3D収集に おける各計数率の変化を示した . 2D収集において， BG-A ctivityか設定値 $(2 \mathrm{kBq} / \mathrm{mL})$ となったときのT+Sの 計数率は21.0kcps, 偶発同時計数率は2.2kcpsであつ た．一方，3D収集においては，T+Sの計数率は $109.8 \mathrm{kcps}$, 偶発同時計数率は36.5kcpsであつた .

\section{3-3 収集データのバラツキ評価}

Fig. 5 ，6に2Dおよび3D収集における各計数率の $\triangle C O V$ を示す．2D収集(Fig. 5)において基準值から $\triangle C O V \pm 2.5 \%$ の計数率領域は，16.5～25.5kcpsであ り, データ数は11個であつた . また, 時間間塥は70分

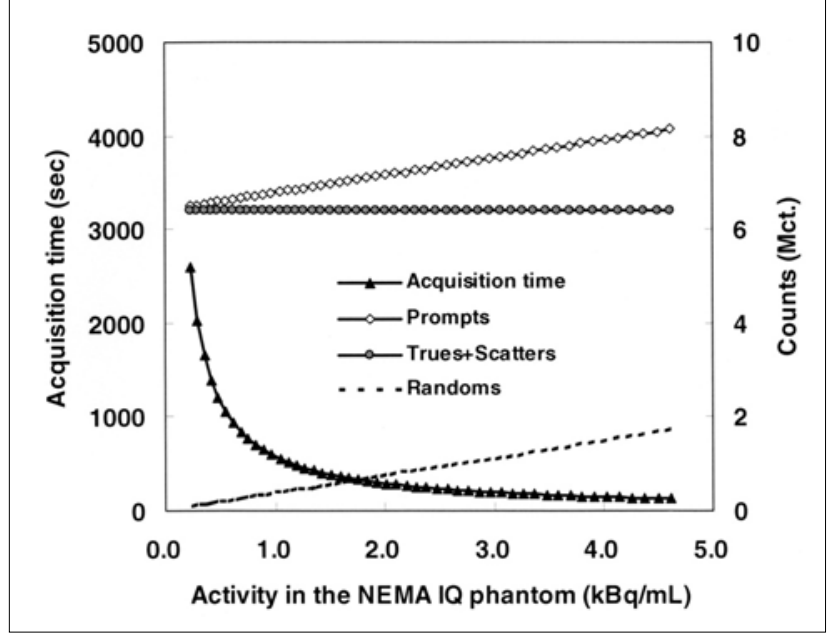

Fig. 1 Changes in acquisition counts and acquisition time in $2 \mathrm{D}$ mode.

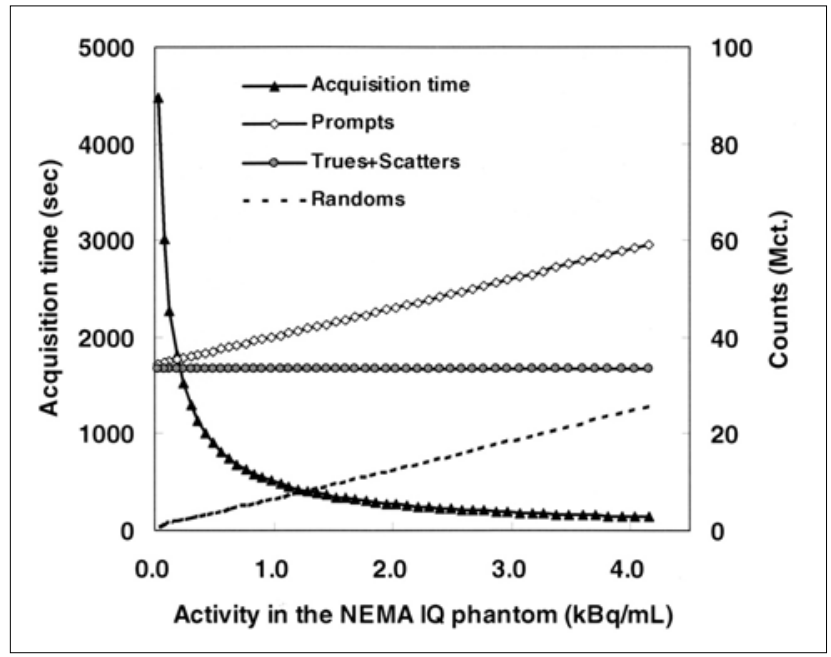

Fig. 2 Changes in acquisition counts and acquisition time in 3D mode.

であった．3D収集(Fig. 6)においては，基準値から $\triangle C O V \pm 2.5 \%$ の計数率領域が , 81.1〜138.5kcpsであ り，データ数は13個であった．また，時間間塥は85分 であった . 計数率の減少に対するCOVの変動につい て，2D収集では，COVが上昇傾向にあった .一方3D 収集では，逆にCOVが減少傾向にあり2D収集と相反 した結果となった .Fig. 7 ,8に計数率の異なる2Dお よび3D収集におけるファントム画像と，37mm けるL/B比を示す .Fig. 5，6に示したように画像ノイ ズは計数率が低くなるに従い2D収集では増加傾向を 示し，3D収集では減少傾向を示し，視覚的にも評価 可能である(Fig. 7) . 2Dおよび3D収集画像のL/B比の 変動について, 計数率の減少に伴いし/B比か増加傾向 を示した．また両者を比較した場合，データのバラツ キは2D収集のほうが大きい傾向を示したが，L/B比は 真值 $(\mathrm{L} / \mathrm{B}=4)$ に近い値を示した(Fig. 8) . 


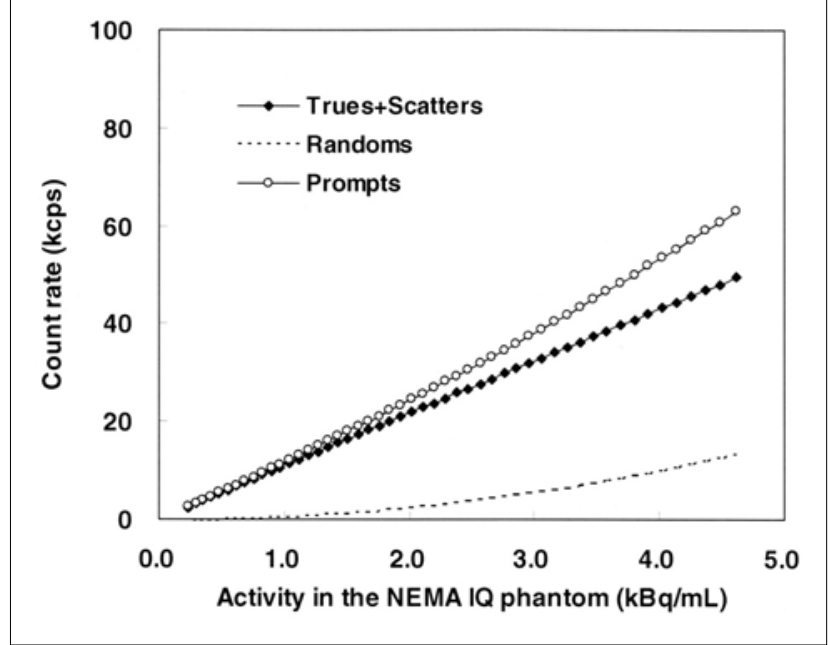

Fig. 3 Count-rate changes in 2D mode.

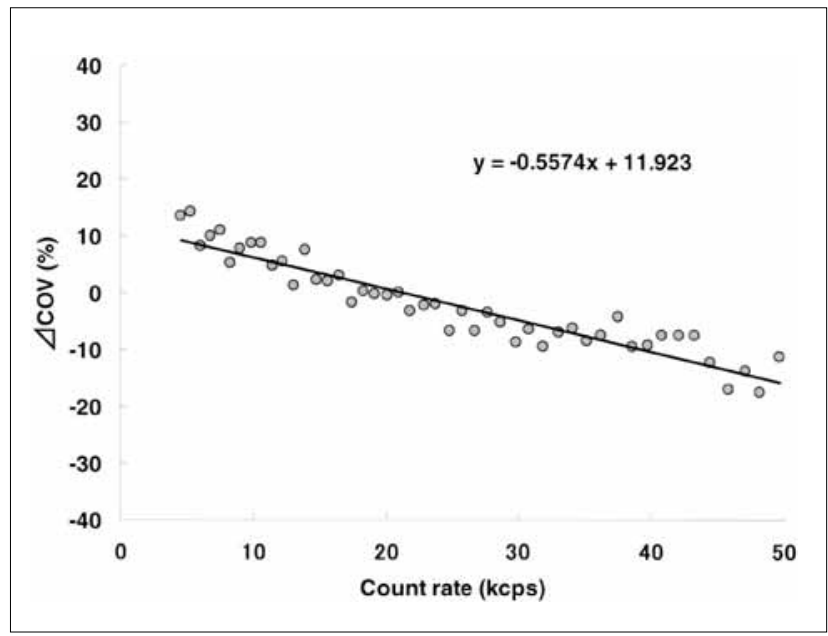

Fig. 5 Changes in $\triangle \mathrm{COV}$ due to count-rate difference in 2D mode.

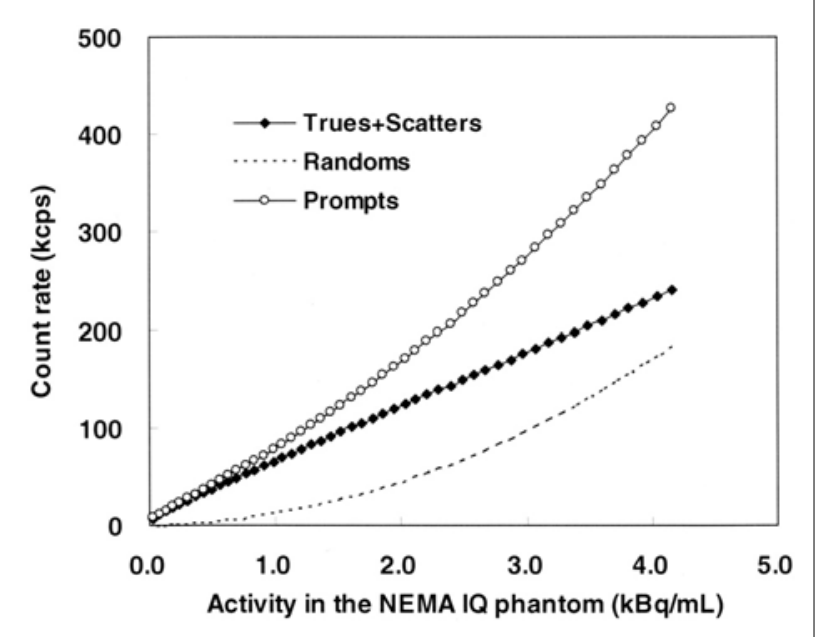

Fig. 4 Count-rate changes in 3D mode.

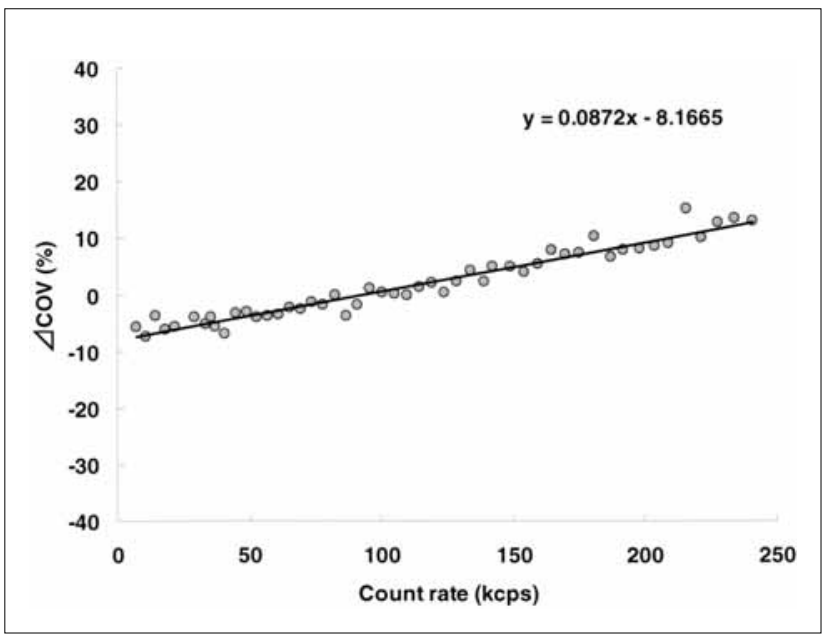

Fig. 6 Changes in $\triangle \mathrm{COV}$ due to count-rate difference in 3D mode.

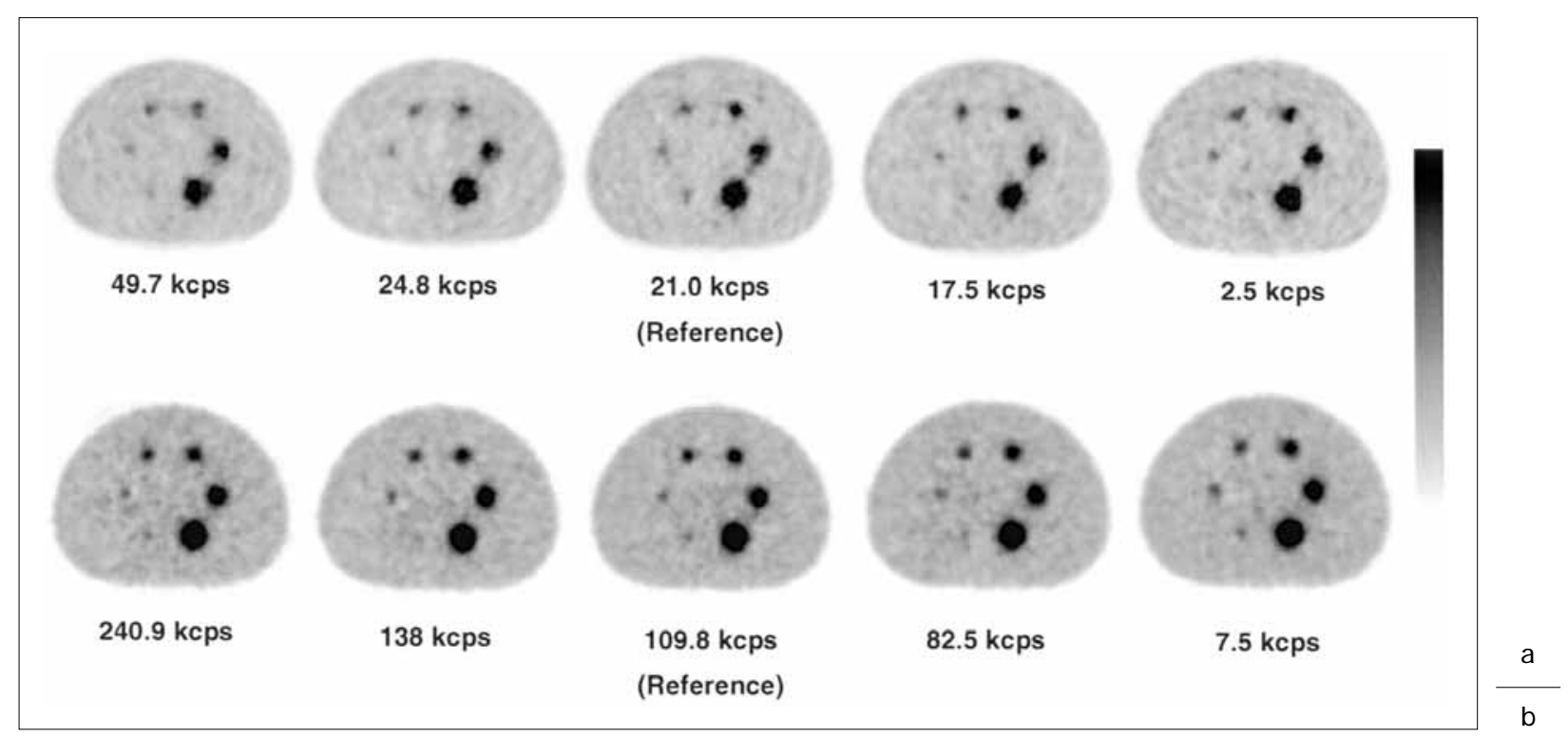

Fig. 7 Two( a) and three( b) dimensional acquisition images with differing count rates. 


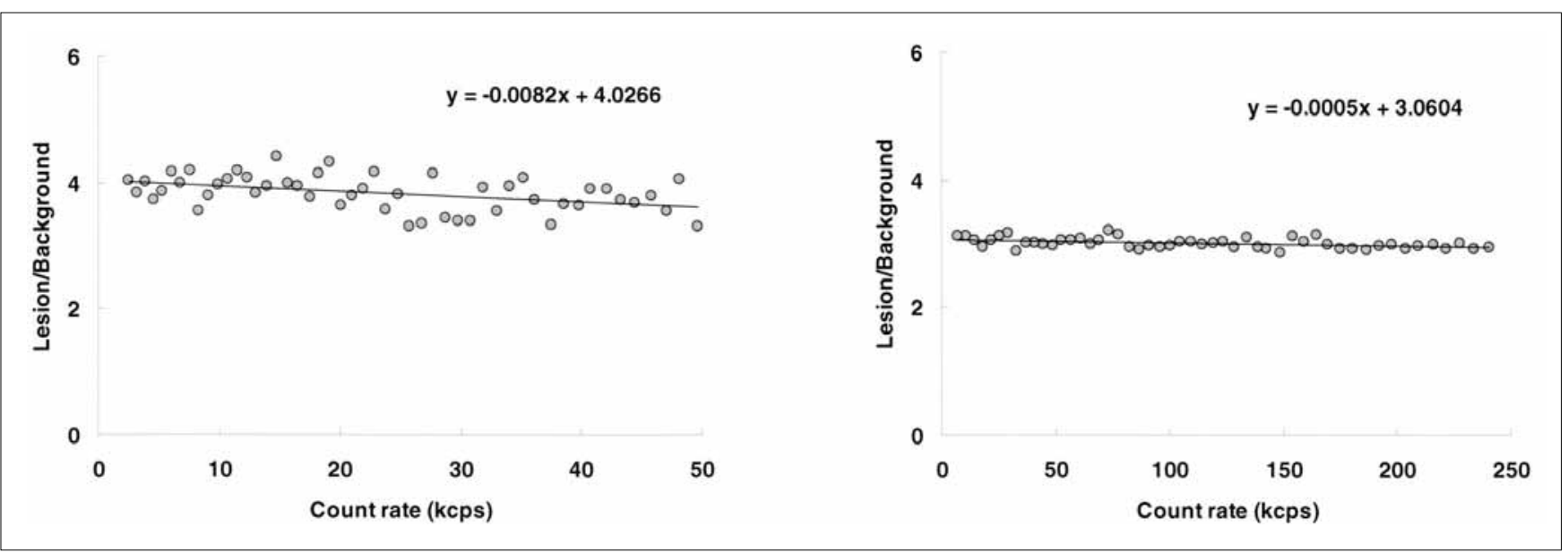

Fig. 8 Lesion/background of $37 \mathrm{~mm} \phi$ of $2 \not($ a) and $3 \phi$ b) acquisition images.

\section{4. 考 察}

本実験方法(2-1項)について，BG：2kBq/mL， HOT : 8kBq/mLのNEMA NU-2 $2001 \mathrm{IQ}$ ファントムを 5 分間収集したときのT+Sのカウント $\left(C_{5 \min }\right)$ を式(1)よ り算出し，高計数率領域よりカウント制御によるダイ ナミック収集を行い偶発同時計数率の違いによる影響 を検討し，画質評価のためのデータ収集方法として妥 当性を検討した．本実験で使用したPET CT装置は， カウント $(\mathrm{T}+\mathrm{S})$ 制御による同一カウントでの収集が可 能であるが, カウント制御による収集が不可能である 装置も存在することから，式(7)に収集時間を制御す ることにより $C_{t}$ を一定にするための必要な収集時間の 算出方法を示す.

$$
S T_{i}=\frac{C_{t}}{C_{1 \min }} \times e^{-\lambda t i}
$$

ここで, $S T_{i}$ はフレームiにおいて $C_{t}$ を得るために必要 な収集時間, $t i$ はレーム (7)を用いてデータ収集を行う場合，各フレームで $S T_{i}$ が異なるため収集開始時刻を計算值と簃密に合わせる 必要がある。

Fig. 1 ，2にカウント制御により得られた2Dおよび 3Dにおける収集力ウントを示した . 谷の結果, T+Sの 収集カウントが一定であり偶発同時計数のみが異なっ た .また，T+Sについて，散乱同時計数のみを解析す ることは不可能であるが, 散乱同時計数は, 真の同時 計数と同樣に放射能濃度に比例し ${ }^{12,13)}$, 計数率に依存 せず両者が一定の割合で存在するため偶発同時計数の 違いについてのみ評価するデータとして適当である． また, 偶発同時計数率が画質に及ぼす影響について式 (5)より $\triangle C O V$ を指標として評価を行った . 偶発同時 計数は, 別の部位で発生した 2 対の消滅放射線が偶 然に同時計測されることであり，偽のLOR(Iine of response)を呈する. 谷のため, 結果的に画像ノイズ として画質に影響を及ぼすことからバラツキを評価す る一般的な指標である $C O V$ を用いた評価は妥当である と考察する .

COVの変動(Fig. 5，6)について , PETにおける画像 ノイズは, 理論的に偶発同時計数率が少なくなるに従 い小さくなるが，2D収集では相反した結果となっ た. $C O V$ は式(4)より算出するが，2D収集において平 均值の変動はなくS.D.のみが上昇傾向であつた．2D， 3D収集の補正項目のなかでとの方法が異なり，かつ $C O V$ に影響を与える因子として散乱同時計数補正が考 えられるが, 今回用いた散乱同時計数補正方法(2D) は, 各検出器において得られた光電ピークとあらかじ め求めた散乱関数により散乱成分を推定し差し引く方 法であるため，COVが一定の割合で変化するのみで光 の傾向か変化することはない，光のほかに，不感時間 による計数損失の影響が考えられた . 本手法における 結果(Fig. 1，2)より，1frameの収集時間が129秒 (2D )，139秒(3D )，1半減期後(109.8分後)の収集時間 が258秒(2D)，270秒(3D)であった．关の結果，2D収 集ではとの影響はなかったが，3D収集では，シンチ レータの不感時間の影響により収集時間が 8 秒増加 し , 全同時計数に対して $5.7 \%$ の計数損失が認められ た．しかし本手法は，T+Sの収集カウントを制御して 収集を行っていることからこれに対する影響は少ない と考えられる . 本研究においては , 統計ノイズの影響 も考えられるが , バックグラウンドノイズの存在と減 衰補正による影響であると考える . バックグラウンド ノイズは単位時間当たり $\mathrm{T}+\mathrm{S}$ 内に一定に存在する . 光 のため, 計数率低下に従い収集時間力増加する本手法 においては, 収集時間が長くなるに従いT+S内の占め る割合が大きくなり，さらに減衰補正により午れか増 大するため，3D収集と比較して感度の劣る2D収集で 
は , T+S内に存在するバックグラウンドノイズの割合 が大きくなるため計数率が低くなるに従いCOVが大き くなったと考える.これは3D収集においても同樣の 現象が生じることであるが，3D収集は2D収集と比較 して感度が4.72倍も高いことから T+S内に占める割合 が小さいためCOVに影響を与えなかったと考察する . 兴のため，3D収集においても偶発同時計数が無視で きる低計数率領域まで収集を行った場合，2D収集と 同樣にCOVが大きくなると推測される .

偶発同時計数率の異なる2Dおよび3D再構成画像を Fig. 7に示した.2D収集では計数率低下に伴い画像ノ イズが劣化し，逆に3D収集では画像ノイズの改善が 視覚的にも評価可能であった . $37 \mathrm{~mm} \phi$ のOT領域の L/B比のバラツキについて(Fig. 8)，2D，3D収集にお いて偶発同時計数率の低下によりコントラスト比か若 干上昇傾向を示したと考える．また，3D収集と比較 して2D収集のほうがバラツキが大きい傾向を示した が，L/B比は真值に近い值を示した . バラツキについ ては, 統計ノイズの影響によるものであると考えら れ，L/B比については，両者の散乱・偶発同時計数の 違いによる影響であると考える. 偶発同時計数の増加 かPPET画像に及ぼす影響として，画像コントラストお よび定量性の低下，画像アーチファクトを引き起こ す.これは，偶発同時計数が空間的情報を持たずFOV 内に一樣に分布するためであり ${ }^{14)}$ ，偶発同時計数の多 い3D収集においてL/B比が劣ったと考えられる .

本研究結果(3-2項)よりBG-A ctivityが $2 \mathrm{kBq} / \mathrm{mL}$ とな ったときのT+Sの計数率が21.0kcps(2D)，109.8kcps (3D)であった . 本研究では, このときのデータを基 準として $\triangle C O V \pm 2.5 \%$ の領域を評価対象データとし た .この計数率領域(画質に影響を及ぼす度合い)は, 収集時間, ファントムに充填する放射能濃度により変
化し，またPET (PET CT) 装置によっても異なる . こ れは現状の装置が, 各メーカにより検出器の種類やサ イズ，画像再構成や各種補正方法(アルゴリズム)など が異なり装置特性が異なるためである，关のため，本 手法を用いる場合，評価を行う各収集時間において有 効な計数率領域を把握したうえで評価を行う必要があ る.さらに本検討法は, 初めに1分間の収集を行い各 装置における基準カウントを算出することから，装置 間の性能(感度)の違いによる影響も加味しており，装 置間で比較をするうえでも有効な手法であると考え る。

PETにおける画質評価を行う場合，Fig. 8に示した ようにデータのバラツキが生じ，1回の実験結果のみ では信頼性に欠ける . 兴のため, 複数の実験データを 得て信頼性を高める必要がある. 本検討法を用いるこ とにより，1回の実験により複数の収集データが得ら れ, 計数率の変化による影響, 複数回の実験によるフ アントム作成誤差, 術者被曝線量を低減することが可 能となり, 評価データの信頼性の向上が示唆された .

5 . 結 語

ファントム実験における画質評価は, 臨床における 収集方法(条件)を決定する一つの因子であることから その役割は大きい．現状の各PET施設において検査目 的や検査環境が異なることから，各施設において产の 評価を行う必要性がある. 本検討法は, 複数回の実験 と比較して信頼性の高いデータの取得，実験の簡略 化, 術者の被曝線量の点て優位であり，実用的である と考えられた .

なお, 本研究の要旨を第26回日本核医学技術学会総 合学術大会(福岡)で発表した。 
参考文献

1) National Electrical Manufacturers A ssociation. NEMA Standards Publication NU 2-2001.: Performance Measurements of Positron Emission Tomographs, (2001).

2) International Electrotechnical Commission. International Standard IEC 61675-1: Radionuclide imaging devices - characteristics and test conditions - Part1 Positron emission tomographs, (1998).

3) (社)日本画像医療システム工業会団体規格 JESRA X-73 : PET装置の性能評価法, (1993) .

4) 藤埜浩一, 岡 尚嗣, 織田圭一, 他 : PET画像の標準化力゙ イドラインに関する研究班報告. 日放技学誌，61(1)，4254, (2005) .

5) 日本核医学技術学会編: 放射線の基礎知識, 最新核医学検 査技術，pp.811，メディカルトリビューン，(2001).

6) Mawlawi O, Podoloff DA, Kohlmyer S, et al.: Performance characteristics of a newly developed PET CT scanner using NEMA standards in 2D and 3D modes. J Nucl Med, 45(10), 1734-1742,(2004).

7) Hudson HM, and L arkin RS: A ccelerated I mage Reconstruction U sing Ordered Subsets of Projection Data. IEEE Trans Med Imaging, 13(4), 594-600,(1994).
8)Defrise M, Kinahan PE, and Townsend DW, et al.: Exact and A pproximate Rebinning A Igorithms for 3-D PET Data. IEEE Trans Med I maging, 16(2), 145-158,(1997).

9) Bergstrom M, Eriksson L, Bohm C, et al.: Correction for scattered radiation in a ring detector positron camera by integral transformation of the projections. J Comput A ssist Tomogr, $7(1), 42-50,(1983)$.

10) Ollinger JM: Model-based scatter correction for fully $3 D$ PET . Phys Med Biol, 41(1), 153-176,(1996).

11) V alk PE, Bailey DL, Townsend DW, et al.: Positron Emis sion Tomography, Basic Science and Clinical Practice. pp.115120, Springer,(2003).

12)鳥塚莞爾 : クリニカルPET, 臨床応用のためのガイドブッ ク . pp.22-33, 先端医療技術研究所, (1997).

13) Brasse $D$, Kinahan PE, Lartizien C, et al.: Correction methods for random coincidences in fully 3D whole-body PET: impact on data and image quality. J Nucl Med, 46(5), 859867,(2005).

14) Phelps ME: PET: Molecular Imaging and Its Biological A pplications, pp.65-67, Springer,(2004).

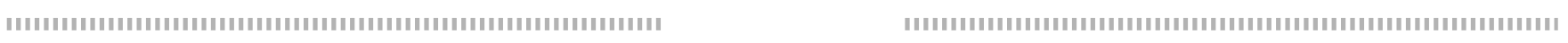

Fig. $12 \mathrm{D}$ 収集における各収集カウントと収集時間の変化

Fig. 2 3D収集における各収集カウントと収集時間の変化

Fig. 3 2D収集における計数率の変化

Fig. 4 3D収集における計数率の変化

Fig. 5 2D収集における計数率の違いによる変動計数の変化

Fig. 6 3D収集における計数率の違いによる変動計数の変化

Fig. 7 計数率の異なる2D (a)，3D (b) 再構成画像

Fig. $82 \mathrm{D}(\mathrm{a}), 3 \mathrm{D}(\mathrm{b})$ 再構成画像の37mm $\phi$ のlesion/background 